\title{
The relevance of Chemistry in Tumor microenvironment of Cancer Patient
}

\author{
Amisha Gupta - Student researcher of Biopsychology \\ Laureate certified Student Researcher | Davidson Young \\ Scholar - \\ ( http://yspw.davidsongifted.org/yspw/users/amishagupta) | \\ Community \\ service ( http://peerknowledgesharing.com/amisha-gupta/) | \\ NATS 2021 1st \\ Place winner ( https://youtu.be/9H-Q0e2PCAw) | Youtube \\ profile : \\ ( https://www.youtube.com/c/AmishaGuptaClassicalMusic) \\ LinkedIn : (h ttps://www.linkedin.com/in/amisha-gupta- \\ 3a6940201/) | Cherry Creek High School - Colorado \\ email: guptaamishagupta@gmail.com
}

\begin{abstract}
The prime mechanisms for the alteration or reshaping of common somatic gene cells into malignant tumor gene cells are transgenic or oncogene activation and tumor-suppresser gene cell dismission. Cancer genetic cells are the propulsion of growing and expansion. On the other side, they are incapable of developing them self. The wen microhabitat is thought of plays an extra energetic role in Wen improvement than merely existing as a bystander. Wen Cells dexterously enroll connective tissue cells. Through several walkways, which then supply Wen Cells with improved Signs, median metabolites, and a favorable environment for tumor expansion and metastasis. Lymphoma or tumor cells and the microhabitat environment work both will promote large expansion and metathetical potential through mutual communication. Understanding the play of the wen or tumor sensitive small environment in Wen Expansion can direct to new routes to target the Wen Small environment for more efficient anti-tumor medications or cures. In this study, we address the methods involved in Wen or tumor cells enrolling connective cells to the prime tumor place. Along with that it also explained and highlighted the small microhabitats environment and tumor development process. We also mentioned some of the possible potential treatment approaches of cancer treatment which can mighty be helpful for better results.
\end{abstract}

Key words: Tumor Microenvironment, Stromal cell, Metastasis, Cancer therapy

\section{Introduction:}

Tumorigenesis seems to be a complex as well as a multistage process wherein the oncogenes and tumorsuppressor genes are mutated one after the other. As just a result, there is indeed a greater likelihood of increased proliferation and resistance to the demise of cells. The majority of human tumor types have several characteristics. This involves the improvement for proliferative signals, as well as avoidance of cell death resistance, replication, invasion activation, development suppressors, angiogenesis induction, metastasis, Immortality, energy metabolism, mutations, chromosomal aberrations and immune evasion tumor-promoting damage the inflammatory process $(1,2)$. Our concentration in cancer research itself has changed over the last few generations again from malignant cancer cells to just the tumor microenvironment, its complex interconnections. Its leukocytes, which includes fibroblasts, tumor microenvironment, endothelial cells, matrix proteins and pericytes, also plays a role in cancer growth (3). Human tumors' are more than a mass of growing dangerous cancer cells, according to several researchers. Through cytokines, secreting stimulatory 
growth factors, chemokines, tumor cells can effectively recruit, vascular cells (6), immune cells (5), and stromal cells (4). To construct this microenvironment, such recruited cells emit growth-promoting signals and intermediate metabolites, as well as modify tissue structure. Cancer cells and their surroundings communicate back and forth, metastatic capability and resulting in increased proliferation and eventually death. Therapeutic techniques targeting that tumour microenvironment also have a lot of promise because the tumor microenvironment actively participates in tumor growth and metastasis rather than being a bystander. Nontumor cells seem believed to be more robust genetically than tumor cells, therefore medicines that target its tumor microenvironment may be less likely to produce adaptation mutations as well as fast spread. However, because of the complicated connections (stromal cells can both stimulate and prevent tumor cell proliferation), cancer therapies targeting the tumor microenvironment must be extremely selective.

\section{The tumor microenvironment's components and collaborators in tumor growth:}

Any tumor seems to be a high complexity tissue made up of both cancerous as well as non-cancerous cells. The presence of stromal body cells is well established fibroblasts, my fibroblasts, and other types of mesenchymal cells inflammatory cells, pericytes, and endothelial cells. It may have to do only with the immune system. accumulating proof tumor cells should recruit and reprogram, according to new research human cells inside the environment to contribute to tumor growth development. Tumor cells and normal cells that sustain them combine to produce a tumor a construction resembling a human organ, and make coordinated efforts quick. Proliferation, invasion, and metastases on a local level. Fibroblasts, immunological cells, and vascular cells make up the majority of either the normal cells inside the tumor microenvironment. Through soluble peregrine signals, the cells were drawn towards the original tumor location as well as established its tumor microenvironment for tumor growth (Fig. 1). This tumor microenvironment attracts fibroblasts. Almost the majority of such supporting cells is fibroblasts. For numerous types of human malignancies, stromal cells play a role. Activate fibroblasts suppress tumour growth over the previous stages. That effect is achieved using conventional progression (7). IL-6 development and gaps junctions among fibroblasts $(8,9)$. Tumor cells then can influence fibroblasts, causing them to grow. CAFs (cancer-associated fibroblasts) in fibroblasts were known to cause cancer through the development of several biomarkers including such -smooth fibroblast activation, desmin, muscle actins, and valentine protein. While researchers must have made substantial contributions to such a subject, its genesis of CAFs is indeed a point of contention. CAFs have a crucial role in supporting development and growth angiogenesis, extracellular matrix remolding (ECM) as well as controlling cell-cell contact (10). Both experimental and clinical research. According to the statistics, tumor cells produce a lot of this substance. TGF-, or converting signaling pathway, is indeed a protein that plays a role in the body. Tran differentiates fibroblasts and is chemotactic to fibroblasts and into CAFs $(11,12)$. CAFs are hypothesized may come from a variety of sources via genetic manipulation, produced by normal fibroblasts. The overall expression of genes in fibroblasts was already found to still be variable. Misses mutations, heterozygosis reduction, as well as numerous times a gene's nucleotide sequence varies. Inactivation or mutation 3-phosphatase of phosphatidylinositol-3,4,5-trisphosphate (PTEN) and p53 are often found in CAFs all around the world dilatation of the main tumor (13). The information for genetics, on either hand, is mixed. Changes as just a factor in causing CAFs still are inconclusive. Indirect control of normal dermal fibroblasts is also possible. Cancer cells are reliant on immune cells to express pro-inflammatory cytokines chromosomes (14). At least one person was hypothesized to also be produced by epithelial, endothelial cells, and, curiously, cancerous cells, in addition to regular fibroblast (Fig. 1). Its myofibroblast would be a type of cell that a kind of cell that has a role in wound healing (15) Laminin is a protein that plays an important role in cell adhesion as well as adhesion. In malignancy, differentiating is suppressed in myofibroblasts. CAFs are being used in a variety of settings, adding to the proof of how they can be useful. Myofibroblasts are generated directly from myofibroblasts (17). Furthermore, vascular cells, such as vascular smooth muscle cells, share markers as well as a shape like myofibroblasts, suggesting suggested CAFs might be produced through mural cells (18). The activation by TG F- releasing of macrophages with platelet-derived growth factor (PDGF) also can activate myofibroblasts indirectly (19). Humans bone tissue mesenchymal stem cells are another possible source of CAFs (hMSCs) also known as multipotent cells, which are found in adulthood marrow then have the ability to develop among multiple mesenchymal tissue lineages (20). Tumor cells produce IL-6 as well as stimulate both Stat 3 and MAPK signalling pathways in hypoxic settings, enhancing the migratory ability of hMSCs $(21,22)$. These hMSCs that were collected always had the potential to become CAFs. Accompanying healthy 
epithelial cells, for example, is also a reservoir of CAFs through completing epithelial-to-mesenchymal transition (EMT) under the reaction of microenvironmental stimuli. TGF-induced proliferating endothelial cells could experience phenotypic conversion into fibroblast-like cells, according to a previous study (23). CAFs isolated from human breasts, on the other hand, have recently been discovered to be genetically altered. Tumor biopsies have always been taken from endothelial cancer patients cellular (26). Moreover, most CAFs have genetic mutations but instead, cancer cells are not even the same, implying which only a small percentage of cancer cells are comparable. Cancer cells with stromal cells could do have the same gene as the source (27). As a result, it's important to think about the repercussions. CAFs generated from tumor cells play a role in tumor progression nonmalignant CAFs' indirect effect on linked cancers tumor cells as a mode of tumor growth facilitation. As a result, our present system appears to be certain CAFs Perhaps of encouraging the neighbors to be nastier, we should inspire them to be more malevolent themselves rather than undertaking the task themselves. CAFs may release stromal cells after being activated. SDF-1 is a protein that attracts circulatory cells. EPCs are vascular endothelial cells that are injected into tumors to help them grow to induce angiogenesis (28). The latest analysis, in particular, shed more light on this. Its involvement of miRNAs inside the tumor microenvironment has been put in the spotlight. In PTEN-deficient stromal fibroblasts, downregulation of miR-320 with overexpression of ETS2 (vets erythroblastosis virus E26 oncogene homolog 2, another of miR-320's direct targets) have been identified as contributing to tumour angiogenesis and tumor cell penetration (29). CAFs induce tamoxifen resistant for luminal breast cancer through IL-6-induced ER-degradation, according to the other study (30). CAFs contribute to medication resistance, according to this study. Research aimed to determine whether CAFs produce a favorable tumor microenvironment could help in the creation of potential anti therapy techniques.

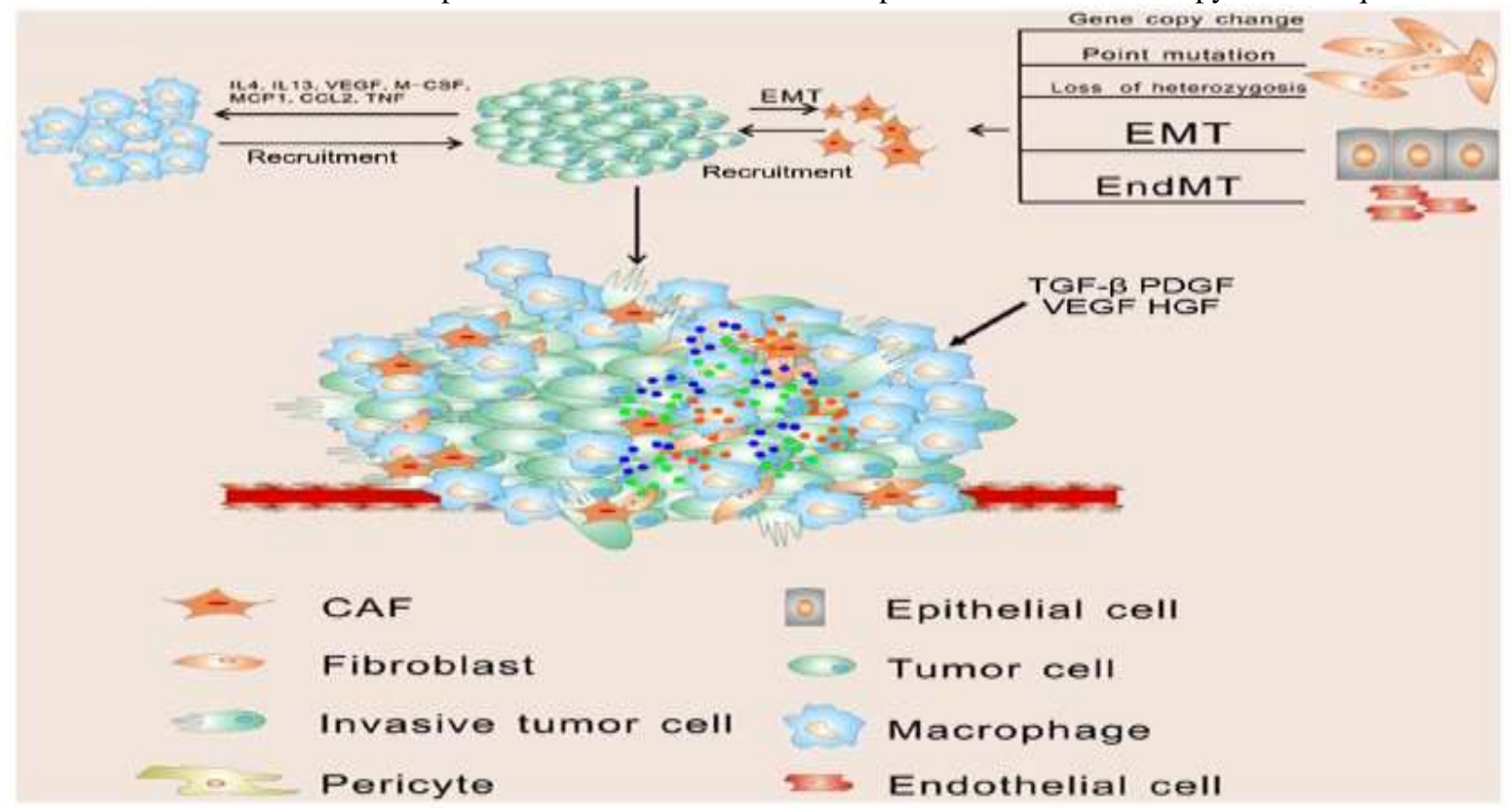

Figure 1: Tumor microenvironment creation. The formation of the tumor microenvironment is shown, as well as the precise mechanisms associated with recruiting for distinct cell types. Cancer-associated fibroblasts (CAFs), endothelial cells, macrophages, epithelial cells, pericytes, and fibroblasts, are all recruited by tumor cells to the tumor's original site. VEG F stands for vascular endothelial growth factor; TN F stands for tumor necrosis factor; CCL 2 stands for chemokine (C-C motif) ligand 2; MC P-1 stands for monocyte chemotactic protein 1; PDGF stands for platelet-derived growth factor; TG $\mathrm{F}$ stands for transforming growth factor; HGF stands for hepatocyte growth; M-CSF stands for macrophage-colony stimulating factor; EndMT stands for endothelial-to-mesenchymal transition, while EMT stands for epithelial-to-mesenchymal transition. CAFs are also involved in medication resistance. The discovery of new therapeutics may be aided by research into how CAFs provide favorable tumor microenvironment techniques for halting tumor growth. Its tumor microenvironment attracts immune cells. Excessive 
quantities of inflammatory processes, such as chemokines and cytokines, are produced when transcriptionally and oncogenic mutation activity occurs. Cytokines and chemokines and, which are produced further into tumor microenvironment can recruit or excite diverse inflammatory cytokines, represent important paracrine and autocrine mediators in tumor formation. As either a result, those "educated" inflammatory cells release additional inflammatory signals and create a cancer-related inflammatory milieu, allowing cancerous cells to evade immune elimination. As a result, those 'trained' inflammatory cells create additional inflammatory signals as well as produce a cancer-related inflammatory microenvironment, which promotes cancer cell proliferation. Immune evasion is the ability to avoid being destroyed by the body's immune system. Eventually, the inflammatory substances Tumor growth is aided by cells. Certain immune cells include Macrophages form the bulk of cells so play a key function inside the immune system. Inflammation caused by cancer Macrophages may split into 2 types. Following diverse stimulation, two main kinds of macrophages emerged. Macrophages that have been traditionally recruited (M1) after being exposed to interferon has anti-cancer properties as well as causes tissue injury responses. Through the reaction of IL-4 or IL-13, macrophages activate in a different way (M2) (31). TAMs (tumor-associated macrophages) are similar to alternate macrophages (M2) macrophages are immune cells that generate a lot of interleukin IL-10. Furthermore, such units have antiinflammatory as well as anti-proliferative properties principles of tissue regeneration (32). VEGF (vascular endothelial growth factor) is indeed a protein produced either by endothelium macrophagecolony stimulating factor (VEG F) (M-CSF) the MCP-1 (monocyte chemotactic protein 1) is a tumorproduced nutrient. Cellular membranes are effectively recruited towards the tumor microenvironment by cells both encouraging migration and ensuring life (33). Surprisingly, a very low rate of MC P-1 causes only minor monocyte infiltration, which leads toward tumor growth, even though a massive concentration causes significant monocyte/macrophage infiltration, which leads to tumor elimination (34). Experiments show the signalling chemicals generated between tumor cells and macrophages operate cooperatively the trigger integrin 41, resulting in microglia in the tumor microenvironment being stimulated (35). Chemokines and chemokine receptors are a large network comprising chemical messengers that regulate both growths of primary tumors as metastasis (36). Tumor cells and chemokine CCL 2 (C-C motif ligand 2) attract inflammatory monocytes these transforms become macrophages that aid ineffective. Sowing as well as development for tumor cells at distant metastatic locations of the lung (37). CCL2 has even been linked with an increase in prostatic size. Macrophage as well as macrophage-mediated tumour development as well as bone metastasis activation of osteoclasts (38). Such researches had yielded excellent results improvements towards our knowledge of a recruiting of microphages to that same tumor's location (Fig. 1). Cancer cells which transcription factor chemokine (C-X-C motif) ligand 2 (CXCL 1/2) may recruit CD11b+Gr1+ myeloid cells through into primary tumor location, where they create chemokines such as S100A8/9, that help cancerous cells survive (39). Melanoma tumors release CCL21, which alters the overall specific immune system between the case of incomplete to tolerogenic, allowing tumor development (40). Additional soluble substances, including prostaglandin E2 (PGE2) but also TGF-, contribute towards tumor growth through suppressing natural killer (NK) cells (41). TNF signaling may facilitate tumor cell escapes from the immune system by causing myeloid-derived suppressive cells that accumulate (42). Bayne et colleagues established revealed cancer factors cause patent ductus arteriosus (PDA) in a spontaneous mouse model colony-stimulating factor of granulocytes and macrophages (GM-CSF). As just a result, the accumulation of Gr-1+CD11b+ polymorphonuclear leukocytes is an accelerated component of an inflammatory response linked to cancer. As a result, anticancer $\mathrm{T}$ cell resistance is suppressed, while antitumor $\mathrm{T}$ cell immunity is promoted the development of a tumor (43). CXCL 12 in particular can migrate, control cancer survival, and proliferation of cells, as well as, directly, tumors can be influenced by vasculature or the recruitment of lymphocytes development (44). Such 'trained' lymphocytes partner up tumor cells including CAFs to generate additional inflammatory molecules, resulting in an inflammatory microenvironment that protects tumors against immune attack. Eventually, such collaboration encourages tumor cell proliferation. Nevertheless, studies have found the link between cancer and inflammation is limited. New medication discovery benefits from progress in identifying inflammation-dependent systems that alter tumor cell chemoattractive, transport, and viability. Knowing both specific biological causes underlying cancer can lead to much more clinical treatment options. This tumor microenvironment attracts vasculature cells. Because satisfy their metabolic 
and nutritional necessities of development, tumors require the formation of the complicated vascular system. Emerging research shows the tumor cells may influence endothelial cells and pericytes, which also are involved in the 'turning of' of such angiogenic switch $(45,46)$. VEG $F$ was unregulated in a spectrum of human malignancies, including kidney (51), lung (47), bladder (50), breast (48), and ovarian (49), according to several investigations (50). Inside a series of in vivo scenarios, VEG F produces a strong angiogenic response. Enterochromaffin cells (Ecs) are activated immediately by VEG F either mitogenic as well as other mechanisms.It has promigratory actions that mobilise endothelial progenitor cells.EPC dynamics are modulated by cells (EPCs). This encourages the separation of EPCs (51). Intriguingly, miR-126 is a microRNA that has a role in endothelial recruiting or metastatic colonisation are regulated by this protein by targeting IGFBP2, PITPNC 1, and MERTK (52). Protein Inhibition of kinase $\mathrm{C}(\mathrm{PKC})$ is important inside the extracellular environment. Phosphorylation of the signal-regulated kinase (ERK) causes pulmonary vascular endothelial cell proliferation (53). PI3K/AKT/mTOR (phosphatidylinositol 3-kinase/AKT/mammalian target of rapamycin) is yet another essential consistently positive that is active like most malignant tumors but is intimately linked to VEG F production both in (HIF-1) dependent and (HIF-1) independent ways during responses with stimulation of PI3K/AKT (54). The stimulation of mTOR was discovered. Squamous cell carcinoma of the head and neck (HNSCC) individuals mTOR inhibition and metastasis resulted in decreased vascularity. lymph node development and metastasis $(55,56)$. Inhibitors that affect signaling including molecules signaling pathways could have been a promising cancer therapeutic method.

\section{Substances that allow tumor cells to 'break free' from their confinement:}

Indicators that promote investment. Both in healthy and pathologic tissues, growth-promoting signals in the microenvironment play a pivotal part. Cells express should be promoted out of a dormant condition to something like an active proliferation condition for body cells. These have strict control over the development of transmission of development hormones which urge itself as well as other cells the enter a cell division as well as development cycle. Simultaneously, development impulses lead to cancermaintaining proliferation, which has been validated as just a presence of chronic. Autocrine and paracrine pathways provide chemical messages to cancer cells. Researchers believe, given past studies, the tumour stroma cells support cancer cells with energy. Messages that support development, such as growth factors as well as chemokines Table I summarizes tumor-promoting factors atoms. Substances are produced through into milieu by stromal cells encourage tumor growth by cellular activation cellular maturation, proliferation, and growth As an example, TGF has been shown to promote EMT as well as invasiveness in cell lines cancerous growths (57). This TGF signaling system could be blocked to minimize intravasation and metastatic implantation inside the lungs and bones (58-62). Including a recent study of Labelle et al, platelets release TGF-1, which activates that TGF/Smad system within tumor cells by increasing invasiveness and metastasis (63). Hepatocyte stimulant (HGF), which was first identified as just a mitogenic peptide from hepatocytes (64), may drive mitogenesis, cell motility, and tissue invasion while also activating MET receptor tyrosine kinase $(65,66)$. According to two surveys, the greater a patient's HGF levels, the less probable she perhaps is to stay into treatment. Their researchers discovered the HGF released by stromal cells engaged my MET, reactivated its mitogen-activated protein kinase (MAPK), also reactivated both phosphatidylinositol-3-OH kinase (PI3K)-AKT signalling pathways. In BRAFmutant melanoma cells, such biological signaling alterations quickly develop a tolerance for RAF inhibitor but also confer resistance to BRAF inhibitor $(67,68)$. Antibodies that target receptors have been produced in contrast with pharmacological inhibitors in tissue suppression. Cetuximab, an EGFR monoclonal antibody, is an effective antitumor medication that can be used to treat a variety of cancers. Cetuximab's efficacy versus chemo- or radioresistant HNSCC has been demonstrated (69). Additional stromal cell-secreted signaling molecules also can encourage cancer cell proliferation. IGF1, VEGF, bFGF, and PDGF, for example, may aid tumor growth by inducing angiogenesis (Table I). Chemokines, in contrast to the signaling pathways, play an essential role in tumor formation. Chemokines were chemotactic cytokines that are generated with inflammatory cytokines. Chemokine signalling is primarily 
involved in cellular transformation, inflammation, and wound healing, as well as tumor growth, angiogenesis, carcinogenesis, and metastasis (73) (72). (Table I).

Table I. Summary of tumor-promoting molecules.

Name

Main function References

OPN Tumor metastasis, protection from apoptosis, induction of tumor-associated

(204-207) inflammatory cells

Galectin-3 Neoplastic transformation, tumor metastasis

VEGF Stimulates angiogenesis regulates vascular permeability

EGF promotes cancer growth, contributes to aggressive behavior

TGF $\beta \quad$ Enhances EMT and invasiveness, regulates inflammation

HGF Angiogenesis, tumorigenesis, tissue regeneration, tumor metastasis

Histamine Increases vascular permeability, pro-inflammatory

TP Angiogenesis, chemotherapy activation, promotes tumor growth

BDNF Tumorigenesis (217)

P-selectin Promotes tumor growth, tumor metastasis, pro-inflammatory

LPA Survival, cell proliferation, migration, tumor metastasis (219)

S1P Survival, vascular permeability, cell invasion (220)

Prothrombin Tumor metastasis, tumor progression (221)

PDGF Angiogenesis, enhances stromal cell survival, proliferation and migration (213)

bFGF Angiogenesis, mitogenic, tumor progression

(213)

SERPINE1 Angiogenesis, tumor invasion (222)

IGF1 Angiogenesis, mitogenic, tumor progression

ANGPT1 Angiogenesis, tumor progression

CCL2 Tumor growth and progression, promotes cancer growth, tumor metastasis,

$(76-78,224)$ tumor macrophage infiltration

CCL3 Angiogenesis, tumor metastasis (225)

CCL5 Tumor growth and progression recruits leukocytes during inflammation $(224,226)$

CCL6 Tumorigenesis, tumor metastasis

CXCL8 Angiogenesis, leukocyte chemoattractant, pro-inflammatory

CCL18 Tumor progression, tumor metastasis

CCL21 Tumor progression, tumor survival and invasion (40)

CCL22 Tumor progression, cell migration, tumor metastasis 
CXCL1 Promotes cancer growth, angiogenesis, cancer chemoresistance, tumor metastasis $(39,74,230,231)$

CXCL2 Tumor growth and progression, angiogenesis, cancer chemoresistance, tumor metastasis

CXCL3 Tumor growth and progression, angiogenesis, tumor metastasis $\quad(224,230,231,234)$

CXCL5 Angiogenesis, tumor metastasis

CXCL6 Angiogenesis, tumor metastasis

CXCL7 Angiogenesis, tumor metastasis

$(230,231,239)$

CXCL8 Tumor growth and progression, angiogenesis, tumor metastasis, (224,231)

CXCL12 Tumor progression, tumor invasion and metastasis

(240-242)

OPN, osteopontin; VEG F, vascular endothelial growth factor; EG F, epidermal growth factor; TG F $\beta$, transforming growth factor- $\beta$; HGF, hepatocyte growth factor; TP, thymidine phosphorylase; BDNF, brain-derived neutrophic factor; LPA, lysophosphatidic acid; S1P, sphingosine

1-phosphate; PDGF, platelet-derived growth factor; bFGF, basic fibroblast growth factor; SER PINE 1, serpin peptidase inhibitor (also known as

plasminogen activator inhibitor-1, PAI1); IGF1, insulin-like growth factor 1; ANG PT1, angoipoietin 1; CCL , C-C motif chemokine; CXCL 5, C-X-C motif chemokine.

pathogenic stimuli and growth factors (70-72). Chemokine signaling is essential for cell transformation, inflammation, and wound healing, as well as tumour growth, angiogenesis, carcinogenesis, and metastasis (73) (72). (Table I).CXC chemokines and CC chemokines are currently the subjects of disease chemokine study. Certain CXC chemokines promote cancer growth by promoting angiogenesis and improving tumor growth. The CXC chemokine group is overexpressed in $70 \%$ of human melanomas and yet is implicated in the development and angiogenesis of CRC tumors (74) metastasis. CXCL1, a cytokine that belongs to it. CXCL $1 / 2$ overexpression attracts CD11b+Gr1+ myeloid cells to the primary tumor location in cancer cells. Ultimately, it improves the survival of the cancer cells by factors S100A8/9 (39). This CC chemokine families' subgroup, which is secreted by stromal cells and also has a variety of roles in the body the development of cancer CCL2, for instance, is thought to be the result of the viral invasion and can cause metastasis (75-78). Additional chemicals implicated in the tumour microenvironment, like osteopontin (OPN), galectin-3, or brain-derived neutrophic factor (BDNF), encourage cancer growth. Moreover, several compounds found inside the vasculature, such as LPA, have been shown to have anti-inflammatory properties. Cancer growth can be aided by stromal cells. S1P with prothrombin are important factors to tumor growth (Table I). Posttranscriptionally, small and non-coding RNAs (miRNAs) are produced. mRNA synthesis, as well as 
storage, are regulated. Certain RNAs play a role in metabolism regulation and origin of tumors (79-81).

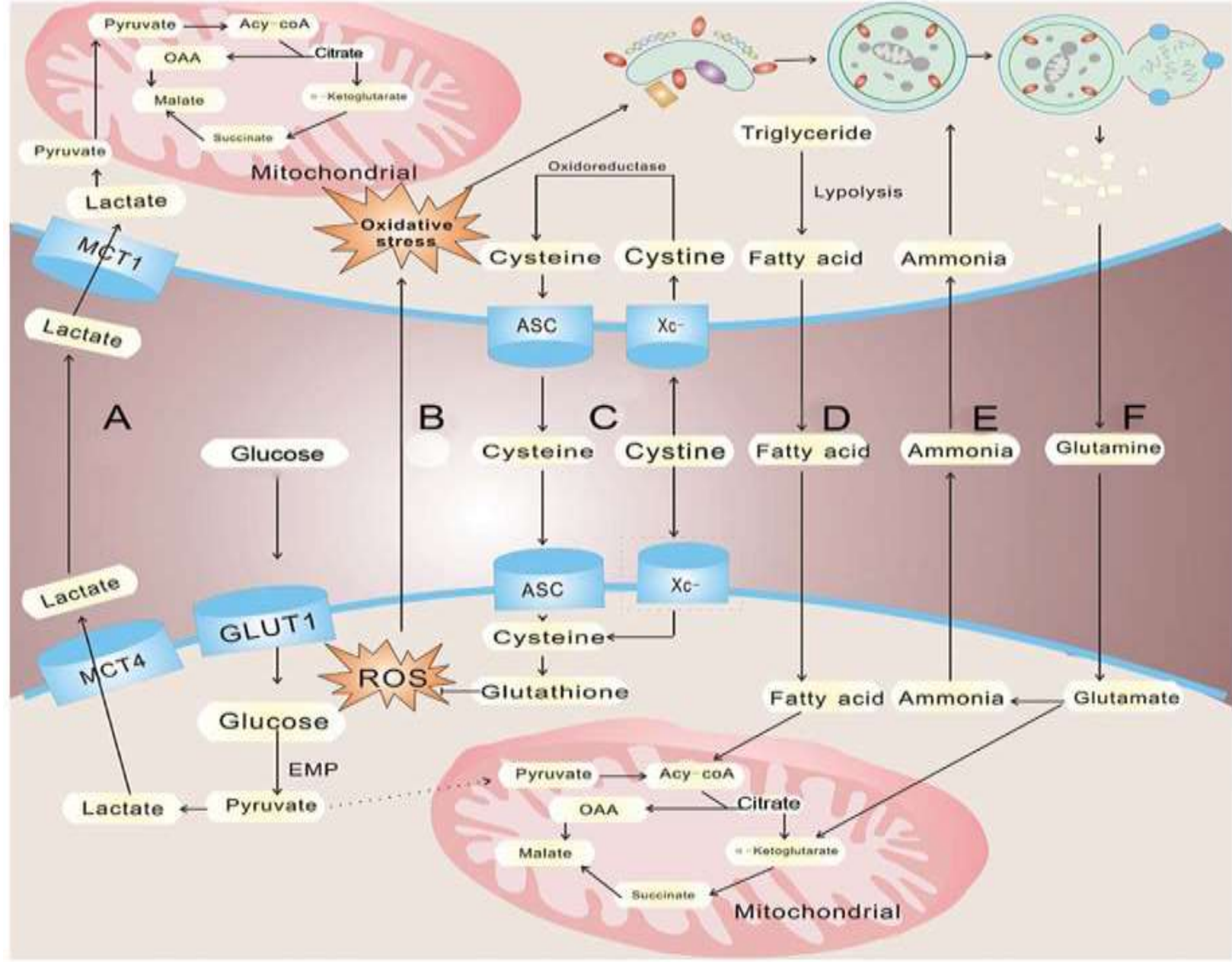

Figure 2 : Summary of the role of the tumor microenvironment in the regulation of cancer cell metabolism. (A) Tumor cells, under hypoxic conditions, secrete

lactate via MCT 4. In response, cancer-associated fibroblasts (CAFs) and oxygenated tumor cells take up the tumor-extruded lactate. (B) Cancer cells induce

ROS production in CAFs, leading to the onset of stromal oxidative stress, which in turn, drives autophagy and provides recycled nutrients via catabolism and

aerobic glycolysis to feed the appetite of adjacent cancer cells. (C) Tumor stromal cells can take up cystine, convert it to the amino acid cysteine, and

then secrete it. Tumor cells then use cysteine to produce glutathione, resulting in increased ROS resistance and survival. (D) Adipocytes provide tumor cells

with fatty acids supplying the energy needs for rapid tumor growth. (E) Glutamine can be hydrolyzed as ammonia in tumor cells and reused by CAFs. (F) CAFs

secrete glutamine into the tumor microenvironment to meet the glutamine needs of the cancer cells. MCT4, monocarboxylate transporter 4; GLUT1: Glucose

transporter 1; ASC: Neutral amino acid transporter A; Xc-: Cystine/glutamate transporter; ROS: Reactive Oxygen Species; OAA: Oxaloacetate.

\section{Implications for therapy:}


To cause carcinogenesis, cancer cells must undergo a wide range of genetic alterations. Since many different forms of cancers, there is a clinical treatment. Our study of human cancers has primarily focused on aggressive cancer cells. Even though cancer treatment has made significant progress, it's still a huge challenge. Currently, the most widely used radiation treatment has major consequences side effects, including even as a patient's immune response is destroyed. Patients rapidly build clinical excellence as a result of this method. As previously stated, the tumor microenvironment plays a role in tumor start and development in a variety of different human cancers, giving researchers hope the therapeutic focus of these processes might be effective for cancer treatment. Research shows that tumor stromal cells, which make up the tumour microenvironment, play a role in chemoresistance. When CCR2 deficient host mice were given doxorubicin, they reacted differently than just a control group. The impact appeared created since a stromal CCL 2/CCR 2 chemokine/chemokine transmitter pathway could attract myeloid cells into doxorubicin-treated tumours, resulting in chemoresistance (194). Likewise, endogenous mesenchymal stem cells (MSCs) were stimulated that produce polyunsaturated fatty acids upon therapy using silver analogues, that shield cancer cells from a variety of chemotherapeutics (195). Our groundbreaking study showed that tumor microenvironment is a major administrator of tolerance to classic cytotoxic therapies, including chemo and radiation, but point up potential targets for improving chemotherapy benefit in patients. Over the latest days, analyzed parameters approaches have been developed, wherein tumour cells, as well as the tumour microenvironment, are both suppressed at the same time. When compared to traditional medicines, such multitargeted techniques offer numerous benefits. On only one side, tumour stromal cells are thought to be processed and ensured, whereas tumours are known to be biologically unstable. As a result, cancer patients are less likely to accumulate adaptable alterations and develop quick tolerance to chemotherapy and radiotherapy. On either extreme, so because tumour microenvironment is comparable in many cancer types, one treatment focus could be used for all of them. Its tumour microenvironment may play a role in a variety of diseases and over one kind of cancer Depending on tumour microenvironment studies,, a variety of methods have been created cancer research, such as liquid biopsy (196) and in silico analysis biology at the molecular level (197). A blood biopsy is utilised to examine the patient. Non-muscle invasive bladder cancer patients have tumour DNA in their urine bladder cancer sufferers and offer a non-invasive treatment option detection of cancer (198). Biomarker profiling in silico The method is being utilised to find GLUT 4-specific inhibitors cancer treatment (199). The findings contributed significantly to customized/precision medicine and also have a high potential for individualised detection. Because of these benefits, cancer therapy that targets the tumour microenvironment has a lot of promise. There still are numerous tumor-promoting elements inside the tumour microenvironment, indicating as blocking or eliminating those signal transduction can prevent cancer from developing. Tumors in a stroma transgenic mouse model treatment with the TGF inhibitor, for example, had fewer blood vessels (200).

Conclusion: The information again for critical involvement of the tumour microenvironment in tumour progression and metastasis is highlighted in this study. As previously stated, tumour start and development are complicated processes as well as multistep processes wherein the tumor microenvironment has a role that could play a role in its success. In this rapid sequence, Cancer cell growth can be influenced by the tumour microenvironment in addition to tumor metastasis. As both a result, medical research should take into account both the intrinsically and extrinsically pathways inside the tumor microenvironment. The significance of the tumor microenvironment in primary and recurrent cancers is being elucidated, with novel areas like secreted miRN As, metabolism and premetastatic are being explored. Targeting this tumor microenvironment in compliance with current clinical techniques has a lot of promise for generating new, more effective treatments. Cancer medicine should transition to a new phase of customized diagnoses as well as therapies that embraces integrated techniques vigorously.

\section{References}

1. De Wever O and Mareel M: Role of tissue stroma in cancer cell invasion. J Pathol 200: 429-447, 2003.

2. Pittenger MF, Mackay AM, Beck SC, Jaiswal RK, Douglas R, Mosca JD, Moorman MA, Simonetti DW, Craig S and Marshak DR: Multilineage potential of adult human mesen- chymal stem cells. Science 284: 143-147, 1999. 
3. Rattigan Y, Hsu JM, Mishra PJ, Glod J and Banerjee D: Interleukin 6 mediated recruitment of mesenchymal stem cellsto the hypoxic tumor milieu. Exp Cell Res 316: 3417-3424, 2010.

4. Karnoub AE, Dash AB, Vo AP, Sullivan A, Brooks MW, Bell GW, Richardson AL, Polyak K, Tubo R and Weinberg RA:Mesenchymal stem cells within tumour stroma promote breast cancer metastasis. Nature 449: 557-563, 2007.

5. Zeisberg EM, Tarnavski O, Zeisberg M, Dorfman AL, McMullen JR, Gustafsson E, Chandraker A, Yuan X, Pu WT, Roberts AB, et al: Endothelial-to-mesenchymal transition contributes to cardiac fibrosis. Nat Med 13: 952-961, 2007.

6. Zeisberg EM, Potenta S, Xie L, Zeisberg M and Kalluri R: Discovery of endothelial to mesenchymal transition as a source for carcinoma-associated fibroblasts. Cancer Res 67: 10123-10128, 2007.

7. Petersen OW, Lind Nielsen H, Gudjonsson T, Villadsen R, Rønnov-Jessen L and Bissell MJ: The plasticity of human breast carcinoma cells is more than epithelial to mesenchymal conversion. Breast Cancer Res 3: 213-217, 2001.

8. Petersen OW, Nielsen HL, Gudjonsson T, Villadsen R, Rank F, Niebuhr E, Bissell MJ and Rønnov-Jessen L: Epithelial to mesenchymal transition in human breast cancer can provide a nonmalignant stroma. Am J Pathol 162: 391-402, 2003.

9. Kurose K, Gilley K, Matsumoto S, Watson PH, Zhou XP and Eng C: Frequent somatic mutations in PTEN and TP53 are mutually exclusive in the stroma of breast carcinomas. Nat Genet 32: 355-357, 2002.

10. Orimo A and Weinberg RA: Stromal fibroblasts in cancer: A novel tumor-promoting cell type. Cell Cycle 5: 1597-1601, 2006.

11. Bronisz A, Godlewski J, Wallace JA, Merchant AS, Nowicki MO, Mathsyaraja H, Srinivasan R, Trimboli AJ, Martin CK, Li F, et al: Reprogramming of the tumour microenvironment by stromal PTEN-regulated miR-320. Nat Cell Biol 14: 159$167,2011$.

12. Sun X, Mao Y, Wang J, Zu L, Hao M, Cheng G, Qu Q, Cui D, Keller ET, Chen X, et al: IL-6 secreted by cancer-associated fibroblasts induces tamoxifen resistance in luminal breast cancer. Oncogene: Jun 9, 2014 (Epub ahead of print). doi:10.1038/onc.2014.158.

13. Sica A: Role of tumour-associated macrophages in cancer- related inflammation. Exp Oncol 32: 153-158, 2010.

14. Sica A, Larghi P, Mancino A, Rubino L, Porta C, Totaro MG, Rimoldi M, Biswas SK, Allavena P and Mantovani A: Macrophage polarization in tumour progression. Semin Cancer Biol 18: 349-355, 2008.

15. Lin EY, Nguyen AV, Russell RG and Pollard JW: Colony-stimu-lating factor 1 promotes progression of mammary tumors tomalignancy. J Exp Med 193: 727-740, 2001.

16. Nesbit M, Schaider H, Miller TH and Herlyn M: Low-level monocyte chemoattractant protein-1 stimulation of monocytes leads to tumor formation in nontumorigenic melanoma cells. J Immunol 166: 6483-6490, 2001.

17. Schmid MC, Avraamides CJ, Dippold HC, Franco I, Foubert P, Ellies LG, Acevedo LM, Manglicmot JR, Song X, Wrasidlo W, et al: Receptor tyrosine kinases and TLR/IL1Rs unexpectedly activate myeloid cell PI3k $\gamma$, a single convergent point promotingtumor inflammation and progression. Cancer Cell 19: 715-727, 2011.

18. Balkwill F: Cancer and the chemokine network. Nat Rev Cancer 4: 540-550, 2004.

19. Qian BZ, Li J, Zhang H, Kitamura T, Zhang J, Campion LR, Kaiser EA, Snyder LA and Pollard JW: CCL2 recruits inflammatory monocytes to facilitate breast-tumour metastasis. Nature 475: 222-225, 2011.

20. Mizutani K, Sud S, McGregor NA, Martinovski G, Rice BT, Craig MJ, Varsos ZS, Roca H and Pienta KJ: The chemokine CCL2 increases prostate tumor growth and bone metastasis through macrophage and osteoclast recruitment. Neoplasia 11: $1235-1242,2009$.

21. Acharyya S, Oskarsson T, Vanharanta S, Malladi S, Kim J, Morris PG, Manova-Todorova K, Leversha M, Hogg N, Seshan VE, et al: A CXCL1 paracrine network links cancer chemoresistance and metastasis. Cell 150: 165-178, 2012. Shields JD, Kourtis IC, Tomei AA, Roberts JM and Swartz MA: Induction of lymphoidlike stroma and immune escape by tumorsthat express the chemokine CCL21. Science 328: 749-752, 2010.

22. Cremer I, Fridman WH and Sautès-Fridman C: Tumor microenvironment in NSCLC suppresses NK cells function. OncoImmunology 1: 244-246, 2012.

23. Zhao X, Rong L, Zhao X, Li X, Liu X, Deng J, Wu H, Xu X, Erben U, Wu P, et al: TNF signaling drives myeloid-derived suppressor cell accumulation. J Clin Invest 122: 4094-4104, 2012.

24. Bayne LJ, Beatty GL, Jhala N, Clark CE, Rhim AD, Stanger BZ and Vonderheide RH: Tumor-derived granulocytemacrophage colony-stimulating factor regulates myeloid inflammation and $\mathrm{T}$ cell immunity in pancreatic cancer. Cancer Cell 21: 822-835, 2012.

25. Würth R, Bajetto A, Harrison JK, Barbieri F and Florio T:CXCL12 modulation of CXCR4 and CXCR7 activity in human glioblastoma stem-like cells and regulation of the tumor micro- environment. Front Cell Neurosci 8: 144, 2014.

26. Bergers G and Benjamin LE: Tumorigenesis and the angiogenic switch. Nat Rev Cancer 3: 401-410, 2003.

27. Bertolini F, Shaked Y, Mancuso P and Kerbel RS: The multi- faceted circulating endothelial cell in cancer: Towards marker and target identification. Nat Rev Cancer 6: 835-845, 2006.

28. Volm M, Koomägi R and Mattern J: Prognostic value of vascular endothelial growth factor and its receptor Flt-1 in squamous cell lung cancer. Int J Cancer 74: 64-68, 1997.

29. Yoshiji H, Gomez DE, Shibuya M and Thorgeirsson UP: Expression of vascular endothelial growth factor, its receptor, and other angiogenic factors in human breast cancer. CancerRes 56: 2013-2016, 1996.

30. Olson TA, Mohanraj D, Carson LF and Ramakrishnan S: Vascular permeability factor gene expression in normal and neoplastic human ovaries. Cancer Res 54: 276-280, 1994.

31. Brown LF, Berse B, Jackman RW, Tognazzi K, Manseau EJ, Dvorak HF and Senger DR: Increased expression of vascular permeability factor (vascular endothelial growth factor) and its receptors in kidney and bladder carcinomas. Am J Pathol 143: 1255-1262, 1993.

32. Asahara T, Takahashi T, Masuda H, Kalka C, Chen D, Iwaguro H, Inai Y, Silver M and Isner JM: VEGF contributes to postnatal neovascularization by mobilizing bone marrow-derived endo- thelial progenitor cells. EMBO J 18: 3964-3972, 1999.

33. Png KJ, Halberg N, Yoshida M and Tavazoie SF: A microRNA regulon that mediates endothelial recruitment and metastasis by cancer cells. Nature 481: 190-194, 2011.

34. Zeng Z, Li YC, Jiao ZH, Yao J and Xue Y: The cross talk betweencGMP signal pathway and PKC in pulmonary endothelial cell angiogenesis. Int J Mol Sci 15: 10185-10198, 2014.

35. Karar J and Maity A: PI3K/AKT/mTOR pathway in angiogenesis.Front Mol Neurosci 4: 51, 2011. 
36. Wang Z, Martin D, Molinolo AA, Patel V, Iglesias-Bartolome R, Degese MS, Vitale-Cross L, Chen Q and Gutkind JS: mTOR co-targeting in cetuximab resistance in head and neck cancers harboring PIK3CA and RAS mutations. J Natl Cancer Inst 106: dju215, 2014.

37. Patel V, Marsh CA, Dorsam RT, Mikelis CM, Masedunskas A, Amornphimoltham P, Nathan CA, Singh B, Weigert R, Molinolo AA, et al: Decreased lymphangiogenesis and lymph node metastasis by mTOR inhibition in head and neck cancer. Cancer Res 71: 7103-7112, 2011.

38. Oft M, Heider KH and Beug H: TGFbeta signaling is necessary for carcinoma cell invasiveness and metastasis. Curr Biol 8: 1243-1252, 1998.

39. Biswas S, Guix M, Rinehart C, Dugger TC, Chytil A, Moses HL, Freeman ML and Arteaga CL: Inhibition of TGF-beta with neutralizing antibodies prevents radiation-induced acceleration ofmetastatic cancer progression. J Clin Invest 117: 13051313, 2007.

40. Padua D, Zhang XH, Wang Q, Nadal C, Gerald WL, Gomis RR and Massagué J: TGFbeta primes breast tumors for lung metastasis seeding through angiopoietin-like 4. Cell 133: 66-77, 2008.

41. Siegel PM, Shu W, Cardiff RD, Muller WJ and Massagué J: Transforming growth factor beta signaling impairs Neuinduced mammary tumorigenesis while promoting pulmonary metastasis.Proc Natl Acad Sci USA 100: 8430-8435, 2003.

42. Yin JJ, Selander K, Chirgwin JM, Dallas M, Grubbs BG, Wieser R, Massagué J, Mundy GR and Guise TA: TGF-beta signaling blockade inhibits PTHrP secretion by breast cancer cells and bone metastases development. J Clin Invest 103: 197-206, 1999.

43. Würth R, Bajetto A, Harrison JK, Barbieri F and Florio T:CXCL12 modulation of CXCR4 and CXCR7 activity in human glioblastoma stem-like cells and regulation of the tumor micro- environment. Front Cell Neurosci 8: 144, 2014.

44. Bergers G and Benjamin LE: Tumorigenesis and the angiogenic switch. Nat Rev Cancer 3: 401-410, 2003.

45. Bertolini F, Shaked Y, Mancuso P and Kerbel RS: The multi- faceted circulating endothelial cell in cancer: Towards marker and target identification. Nat Rev Cancer 6: 835-845, 2006.

46. Volm M, Koomägi R and Mattern J: Prognostic value of vascular endothelial growth factor and its receptor Flt-1 in squamous cell lung cancer. Int J Cancer 74: 64-68, 1997.

47. Yoshiji H, Gomez DE, Shibuya M and Thorgeirsson UP: Expression of vascular endothelial growth factor, its receptor, and other angiogenic factors in human breast cancer. CancerRes 56: 2013-2016, 1996.

48. Olson TA, Mohanraj D, Carson LF and Ramakrishnan S: Vascular permeability factor gene expression in normal and neoplastic human ovaries. Cancer Res 54: 276-280, 1994.

49. Brown LF, Berse B, Jackman RW, Tognazzi K, Manseau EJ, Dvorak HF and Senger DR: Increased expression of vascular permeability factor (vascular endothelial growth factor) and its receptors in kidney and bladder carcinomas. Am J Pathol 143: 1255-1262, 1993.

50. Asahara T, Takahashi T, Masuda H, Kalka C, Chen D, Iwaguro H, Inai Y, Silver M and Isner JM: VEGF contributes to postnatal neovascularization by mobilizing bone marrow-derived endo- thelial progenitor cells. EMBO J 18: 3964-3972, 1999.

51. Png KJ, Halberg N, Yoshida M and Tavazoie SF: A microRNA regulon that mediates endothelial recruitment and metastasis by cancer cells. Nature 481: 190-194, 2011.

52. Zeng Z, Li YC, Jiao ZH, Yao J and Xue Y: The cross talk betweencGMP signal pathway and PKC in pulmonary endothelial cell angiogenesis. Int J Mol Sci 15: 10185-10198, 2014.

53. Karar J and Maity A: PI3K/AKT/mTOR pathway in angiogenesis.Front Mol Neurosci 4: 51, 2011.

54. Wang Z, Martin D, Molinolo AA, Patel V, Iglesias-Bartolome R, Degese MS, Vitale-Cross L, Chen Q and Gutkind JS: mTOR co-targeting in cetuximab resistance in head and neck cancers harboring PIK3CA and RAS mutations. J Natl Cancer Inst 106: dju215, 2014.

55. Patel V, Marsh CA, Dorsam RT, Mikelis CM, Masedunskas A, Amornphimoltham P, Nathan CA, Singh B, Weigert R, Molinolo AA, et al: Decreased lymphangiogenesis and lymph node metastasis by mTOR inhibition in head and neck cancer. Cancer Res 71: 7103-7112, 2011.

56. Oft M, Heider $\mathrm{KH}$ and Beug H: TGFbeta signaling is necessary for carcinoma cell invasiveness and metastasis. Curr Biol 8: 1243-1252, 1998.

57. Biswas S, Guix M, Rinehart C, Dugger TC, Chytil A, Moses HL, Freeman ML and Arteaga CL: Inhibition of TGF-beta with neutralizing antibodies prevents radiation-induced acceleration ofmetastatic cancer progression. J Clin Invest 117: 13051313, 2007.

58. Padua D, Zhang XH, Wang Q, Nadal C, Gerald WL, Gomis RR and Massagué J: TGFbeta primes breast tumors for lung metastasis seeding through angiopoietin-like 4. Cell 133: 66-77, 2008.

59. Siegel PM, Shu W, Cardiff RD, Muller WJ and Massagué J: Transforming growth factor beta signaling impairs Neuinduced mammary tumorigenesis while promoting pulmonary metastasis.Proc Natl Acad Sci USA 100: 8430-8435, 2003.

61. Yin JJ, Selander K, Chirgwin JM, Dallas M, Grubbs BG, Wieser R, Massagué J, Mundy GR and Guise TA: TGF-beta signaling blockade inhibits PTHrP secretion by breast cancer cells and bone metastases development. J Clin Invest 103: 197-206, 1999 .

60. Kang Y, He W, Tulley S, Gupta GP, Serganova I, Chen CR, Manova-Todorova K, Blasberg R, Gerald WL and Massagué J: Breast cancer bone metastasis mediated by the Smad tumorsuppressor pathway. Proc Natl Acad Sci USA 102: 1390913914,2005 .

61. Labelle M, Begum S and Hynes RO: Direct signaling between platelets and cancer cells induces an epithelial-mesenchymalliketransition and promotes metastasis. Cancer Cell 20: 576-590, 2011.

62. Nakamura T, Nishizawa T, Hagiya M, Seki T, Shimonishi M, Sugimura A, Tashiro K and Shimizu S: Molecular cloning and expression of human hepatocyte growth factor. Nature 342: 440-443, 1989.

63. Birchmeier C, Birchmeier W, Gherardi E and Vande Woude GF:Met, metastasis, motility and more. Nat Rev Mol Cell Biol 4: $915-925,2003$.

64. Matsumoto K and Nakamura T: Hepatocyte growth factor and the Met system as a mediator of tumor-stromal interactions. Int JCancer 119: 477-483, 2006.

65. Wilson TR, Fridlyand J, Yan Y, Penuel E, Burton L, Chan E, Peng J, Lin E, Wang Y, Sosman J, et al: Widespread potential forgrowth-factor-driven resistance to anticancer kinase inhibitors. Nature 487: 505-509, 2012. 
66. Straussman R, Morikawa T, Shee K, Barzily-Rokni M, Qian ZR, Du J, Davis A, Mongare MM, Gould J, Frederick DT, et al: Tumour micro-environment elicits innate resistance to RAF inhibitors through HGF secretion. Nature 487: 500-504, 2012.

67. Zhou P, Li H, Wheeler S, Grandis JR, Stabile LA and Egloff AM: Generation of head and neck cancer patient-derived xenografts with in vivo acquired cetuximab resistance. Clin Cancer Res 21 (Suppl 4): B39, 2015.

68. Rossi D and Zlotnik A: The biology of chemokines and their receptors. Annu Rev Immunol 18: 217-242, 2000.

69. Murphy PM, Baggiolini M, Charo IF, Hébert CA, Horuk R, Matsushima K, Miller LH, Oppenheim JJ and Power CA: International union of pharmacology. XXII. Nomenclature for chemokine receptors. Pharmacol Rev 52: 145-176, 2000.

70. Zlotnik A and Yoshie O: Chemokines: A new classificationsystem and their role in immunity. Immunity 12: 121-127, 2000.

71. Dhawan P and Richmond A: Role of CXCL1 in tumorigenesis ofmelanoma. J Leukoc Biol 72: 9-18, 2002.

72. Wang D, Wang H, Brown J, Daikoku T, Ning W, Shi Q, Richmond A, Strieter R, Dey SK and DuBois RN: CXCL1 induced by prostaglandin E2 promotes angiogenesis in colorectalcancer. J Exp Med 203: 941-951, 2006.

73. Karunagaran D, Tzahar E, Beerli RR, Chen X, Graus-Porta D, Ratzkin BJ, Seger R, Hynes NE and Yarden Y: ErbB-2 is common auxiliary subunit of NDF and EGF receptors: Implications for breast cancer. EMBO J 15: 254-264, 1996.

74. Conti I and Rollins BJ: CCL2 (monocyte chemoattractant protein-1) and cancer. Semin Cancer Biol 14: 149-154, 2004.

75. Craig MJ and Loberg RD: CCL2 (monocyte chemoattractant protein-1) in cancer bone metastases. Cancer Metastasis Rev 25:611-619, 2006.

76. Popivanova BK, Kostadinova FI, Furuichi K, Shamekh MM, Kondo T, Wada T, Egashira K and Mukaida N: Blockade of a chemokine, CCL2, reduces chronic colitis-associated carcino- genesis in mice. Cancer Res 69: 7884-7892, 2009.

77. Rottiers V and Näär AM: MicroRNAs in metabolism and metabolic disorders. Nat Rev Mol Cell Biol 13: 239-250, 2012.

78. Krützfeldt J and Stoffel M: MicroRNAs: A new class of regu- latory genes affecting metabolism. Cell Metab 4: 9-12, 2006.

79. Calin GA and Croce CM: MicroRNA signatures in human cancers. Nat Rev Cancer 6: 857-866, 2006.

80. Kosaka N, Iguchi H, Yoshioka Y, Takeshita F, Matsuki Y and Ochiya T: Secretory mechanisms and intercellular transfer of microRNAs in living cells. J Biol Chem 285: 17442-17452, 2010.

81. Zhang J, Zhao H, Gao Y and Zhang W: Secretory miRNAs as novel cancer biomarkers. Biochim Biophys Acta 1826: 32 43, 2012.

82. Xu D and Tahara H: The role of exosomes and microRNAs in senescence and aging. Adv Drug Deliv Rev 65: 368-375, 2013.

83. Kosaka N, Iguchi H, Yoshioka Y, Hagiwara K, Takeshita F and Ochiya T: Competitive interactions of cancer cells and normal cells via secretory microRNAs. J Biol Chem 287: 1397-1405, 2012.

84. Yang M, Chen J, Su F, Yu B, Su F, Lin L, Liu Y, Huang JDand Song E: Microvesicles secreted by macrophages shuttle invasion-potentiating microRNAs into breast cancer cells. Mol Cancer 10: 117, 2011.

85. Fabbri M, Paone A, Calore F, Galli R, Gaudio E, Santhanam R,Lovat F, Fadda P, Mao C, Nuovo GJ, et al: MicroRNAs bind to Toll-like receptors to induce prometastatic inflammatory response. Proc Natl Acad Sci USA 109: E2110-E2116, 2012.

86. Roth C, Rack B, Müller V, Janni W, Pantel K and Schwarzenbach H: Circulating microRNAs as blood-based markers for patients with primary and metastatic breast cancer. Breast Cancer Res 12: R90, 2010.

87. Mitchell PS, Parkin RK, Kroh EM, Fritz BR, Wyman SK, Pogosova-Agadjanyan EL, Peterson A, Noteboom J, O'Briant KC, Allen A, et al: Circulating microRNÂs as stable blood-based markers for cancer detection. Proc Natl Acad Sci USA 105: 10513-10518, 2008.

88. Cairns RA, Harris IS and Mak TW: Regulation of cancer cell metabolism. Nat Rev Cancer 11: 85-95, 2011.

89. Vander Heiden MG, Cantley LC and Thompson CB: Under- standing the Warburg effect: The metabolic requirements of cellproliferation. Science 324: 1029-1033, 2009.

90. Lunt SY and Vander Heiden MG: Aerobic glycolysis: Meeting the metabolic requirements of cell proliferation. Annu Rev Cell Dev Biol 27: 441-464, 2011.

91. Riemann A, Schneider B, Ihling A, Nowak M, Sauvant C,Thews O and Gekle M: Acidic environment leads to ROS-induced MAPK signaling in cancer cells. PLoS One 6: e22445, 2011.

92. Fischer K, Hoffmann P, Voelkl S, Meidenbauer N, Ammer J, Edinger M, Gottfried E, Schwarz S, Rothe G, Hoves S, et al: Inhibitory effect of tumor cell-derived lactic acid on humanT cells. Blood 109: 3812-3819, 2007.

93. Walenta S and Mueller-Klieser WF: Lactate: Mirror and motor of tumor malignancy. Semin Radiat Oncol 14: 267-274, 2004.

94. Rattigan YI, Patel BB, Ackerstaff E, Sukenick G, Koutcher JA, Glod JW and Banerjee D: Lactate is a mediator of metabolic cooperation between stromal carcinoma associated fibroblasts and glycolytic tumor cells in the tumor microenvironment. Exp Cell Res 318: 326-335, 2012.

95. Végran F, Boidot R, Michiels C, Sonveaux P and Feron O: Lactate influx through the endothelial cell monocarboxylate transporter MCT1 supports an NF-אB/IL-8 pathway that drives tumor angiogenesis. Cancer Res 71: 2550-2560, 2011.

96. Semenza GL: Tumor metabolism: Cancer cells give and take lactate. J Clin Invest 118: 3835-3837, 2008.

97. Feron O: Pyruvate into lactate and back: From the Warburg effect to symbiotic energy fuel exchange in cancer cells. Radiother Oncol 92: 329-333, 2009.

98. Sonveaux P, Végran F, Schroeder T, Wergin MC, Verrax J, Rabbani ZN, De Saedeleer CJ, Kennedy KM, Diepart C, Jordan BF, et al: Targeting lactate-fueled respiration selectivelykills hypoxic tumor cells in mice. J Clin Invest 118: 39303942,2008 .

99. Koukourakis MI, Giatromanolaki A, Harris AL and Sivridis E: Comparison of metabolic pathways between cancer cells and stromal cells in colorectal carcinomas: A metabolic survival role for tumor-associated stroma. Cancer Res 66: 632$637,2006$.

100. Nieman KM, Kenny HA, Penicka CV, Ladanyi A, Buell- Gutbrod R, Zillhardt MR, Romero IL, Carey MS, Mills GB, Hotamisligil GS, et al: Adipocytes promote ovarian cancer metastasis and provide energy for rapid tumor growth. Nat Med 17: 1498-1503, 2011.

101. Marie SK and Shinjo SM: Metabolism and brain cancer. Clinics(Sao Paulo) 66 (Suppl 1): 33-43, 2011.

102. Hirayama A, Kami K, Sugimoto M, Sugawara M, Toki N, Onozuka H, Kinoshita T, Saito N, Ochiai A, Tomita M, et al: Quantitative metabolome profiling of colon and stomach cancermicroenvironment by capillary electrophoresis time-of- 
flight mass spectrometry. Cancer Res 69: 4918-4925, 2009.

103. Ko YH, Lin Z, Flomenberg N, Pestell RG, Howell A, Sotgia F, Lisanti MP and Martinez-Outschoorn UE: Glutamine

fuels a vicious cycle of autophagy in the tumor stroma and oxidative mitochondrial metabolism in epithelial cancer cells:

104. Implicationsfor preventing chemotherapy resistance. Cancer Biol Ther 12: 1085-1097, 2011.

105. Filipp FV, Ratnikov B, De Ingeniis J, Smith JW, Osterman AL and Scott DA: Glutamine-fueled mitochondrial metabolism is decoupled from glycolysis in melanoma. Pigment Cell Melanoma Res 25: 732-739, 2012.

107. Jain M, Nilsson R, Sharma S, Madhusudhan N, Kitami T, Souza AL, Kafri R, Kirschner MW, Clish CB and Mootha VK:

108. Metabolite profiling identifies a key role for glycine in rapid cancer cell proliferation. Science 336: 1040-1044, 2012

106. Okamoto K, Toyokuni S, Kim WJ, Ogawa O, Kakehi Y, Arao S, Hiai H and Yoshida O: Overexpression of human mut Thomologue gene messenger RNA in renal-cell carcinoma: evidence of persistent oxidative stress in cancer. Int $\mathrm{J}$ Cancer 65:437-441, 1996.

107. Gackowski D, Banaszkiewicz Z, Rozalski R, Jawien A and Olinski R: Persistent oxidative stress in colorectal carcinoma patients. Int J Cancer 101: 395-397, 2002.

108. Toyokuni S, Okamoto K, Yodoi J and Hiai H: Persistent oxidativestress in cancer. FEBS Lett 358: 1-3, 1995.

109. Zhou Y, Hileman EO, Plunkett W, Keating MJ and Huang P: Free radical stress in chronic lymphocytic leukemia cells and itsrole in cellular sensitivity to ROS-generating anticancer agents. Blood 101: 4098-4104, 2003.

110. Szatrowski TP and Nathan CF: Production of large amountsof hydrogen peroxide by human tumor cells. Cancer Res 51: 794-798, 1991.

111. Grivennikov SI, Greten FR and Karin M: Immunity, inflam- mation, and cancer. Cell 140: 883-899, 2010.

112. Ishikawa K, Takenaga K, Akimoto M, Koshikawa N, Yamaguchi A, Imanishi H, Nakada K, Honma Y and Hayashi J: ROS-generating mitochondrial DNA mutations can regulate tumor cell metastasis. Science 320: 661-664, 2008.

113. Trachootham D, Alexandre J and Huang P: Targeting cancer cells by ROS-mediated mechanisms: A radical therapeutic approach? Nat Rev Drug Discov 8: 579-591, 2009.

114. Martinez-Outschoorn UE, Lin Z, Trimmer C, Flomenberg N, Wang C, Pavlides S, Pestell RG, Howell A, Sotgia F and Lisanti MP: Cancer cells metabolically 'fertilize' the tumor microenvironment with hydrogen peroxide, driving the Warburgeffect: Implications for PET imaging of human tumors. Cell Cycle 10: 2504-2520, 2011.

115. Mathew R, Karantza-Wadsworth V and White E: Role of autophagy in cancer. Nat Rev Cancer 7: 961-967, 2007.

116. Baehrecke EH: Autophagy: Dual roles in life and death? Nat Rev Mol Cell Biol 6: 505-510, 2005.

117. Eisenberg-Lerner A and Kimchi A: The paradox of autophagy and its implication in cancer etiology and therapy. Apoptosis 14:376-391, 2009.

118. Pavlides S, Tsirigos A, Migneco G, Whitaker-Menezes D, Chiavarina B, Flomenberg N, Frank PG, Casimiro MC, Wang C, Pestell RG, et al: The autophagic tumor stroma model of cancer:Role of oxidative stress and ketone production in fueling tumor cell metabolism. Cell Cycle 9: 3485-3505, 2010.

119. Martinez-Outschoorn UE, Balliet RM, Rivadeneira DB, Chiavarina B, Pavlides S, Wang C, Whitaker-Menezes D, Daumer KM, Lin Z, Witkiewicz AK, et al: Oxidative stress in cancer associated fibroblasts drives tumor-stroma coevolution: A new paradigm for understanding tumor metabolism, the field effect and genomic instability in cancer cells. Cell Cycle 9: 3256-3276, 2010.

120. Bonuccelli G, Tsirigos A, Whitaker-Menezes D, Pavlides S, Pestell RG, Chiavarina B, Frank PG, Flomenberg N, Howell A,Martinez-Outschoorn UE, et al: Ketones and lactate 'fuel' tumor growth and metastasis: Evidence that epithelial cancer cells use oxidative mitochondrial metabolism. Cell Cycle 9: 3506-3514, 2010.

121. Martinez- Out scho or n UE, Trimmer C, Lin Z, Whitaker-Menezes D, Chiavarina B, Zhou J, Wang C, Pavlides S, Martinez-Cantarin MP, Capozza F, et al: Autophagy in cancer associated fibroblasts promotes tumor cell survival: Role of hypoxia, HIF1 induction and NFאB activation in the tumorstromal microenvironment. Cell Cycle 9: 3515-3533, 2010.

122. Chiavarina B, Whitaker-Menezes D, Migneco G, Martinez- Outschoorn UE, Pavlides S, Howell A, Tanowitz HB, Casimiro MC, Wang C, Pestell RG, et al: HIF1-alpha functions as a tumor promoter in cancer associated fibroblasts, and as a tumorsuppressor in breast cancer cells: Autophagy drives compartment-specific oncogenesis. Cell Cycle 9: 3534-3551, 2010.

123. Martinez-Outschoorn UE, Whitaker-Menezes D, Pavlides S,Chiavarina B, Bonuccelli G, Casey T, Tsirigos A, Migneco G, Witkiewicz A, Balliet R, et al: The autophagic tumor stroma model of cancer or 'battery-operated tumor growth': A simple solution to the autophagy paradox. Cell Cycle 9: 4297-4306, 2010.

124. Salem AF, Whitaker-Menezes D, Lin Z, Martinez- Outschoorn UE, Tanowitz HB, Al-Zoubi MS, Howell A, Pestell RG, Sotgia F and Lisanti MP: Two-compartment tumor metabolism: Autophagy in the tumor microenvironment and oxidative mitochondrial metabolism (OXPHOS) in cancer cells. Cell Cycle 11: 2545-2556, 2012.Zhang W, Trachootham D, Liu J, Chen G, Pelicano H, Garcia-Prieto C, Lu W, Burger JA, Croce CM, Plunkett W, et al: Stromal control of cystine metabolism promotes cancer cell survival in chronic lymphocytic leukaemia. Nat Cell Biol 14: 276286, 2012.

125. Carmeliet $P$ and Jain RK: Molecular mechanisms and clinical applications of angiogenesis. Nature 473: 298-307, 2011.

126. Risau W: Mechanisms of angiogenesis. Nature 386: 671-674, 1997.

127. Carmeliet P and Jain RK: Angiogenesis in cancer and other diseases. Nature 407: 249-257, 2000.

128. Leek RD, Lewis CE, Whitehouse R, Greenall M, Clarke J and Harris AL: Association of macrophage infiltration with angio- genesis and prognosis in invasive breast carcinoma. CancerRes 56: 4625-4629, 1996.

129. Polverini PJ and Leibovich SJ: Induction of neovascularization in vivo and endothelial proliferation in vitro by tumorassociatedmacrophages. Lab Invest 51: 635-642, 1984.

130. O'Sullivan C, Lewis CE, Harris AL and McGee JO: Secretion ofepidermal growth factor by macrophages associated with breastcarcinoma. Lancet 342: 148-149, 1993.

131. Lewis CE, Leek R, Harris A and McGee JO: Cytokine regulation of angiogenesis in breast cancer: The role of tumorassociated macrophages. J Leukoc Biol 57: 747-751, 1995.

132. Harmey JH, Dimitriadis E, Kay E, Redmond HP and Bouchier-Hayes D: Regulation of macrophage production of vascular endothelial growth factor (VEGF) by hypoxia and trans-forming growth factor beta-1. Ann Surg Oncol 5: 271-278, 
1998.

133. Stockmann C, Doedens A, Weidemann A, Zhang N, Takeda N, Greenberg JI, Cheresh DA and Johnson RS: Deletion of vascularendothelial growth factor in myeloid cells accelerates tumori- genesis. Nature 456: 814-818, 2008.

134. Bingle L, Lewis CE, Corke KP, Reed MW and Brown NJ: Macrophages promote angiogenesis in human breast tumour spheroids in vivo. Br J Cancer 94: 101-107, 2006.

135. Voronov E, Shouval DS, Krelin Y, Cagnano E, Benharroch D, Iwakura Y, Dinarello CA and Apte RN: IL-1 is required for tumor invasiveness and angiogenesis. Proc Natl Acad Sci USA 100: 2645-2650, 2003.

136. Chen P, Huang Y, Bong R, Ding Y, Song N, Wang X, Song X and Luo Y: Tumor-associated macrophages promote angiogenesis and melanoma growth via adrenomedullin in a paracrine and autocrine manner. Clin Cancer Res 17: 72307239, 2011.

137. Mazzieri R, Pucci F, Moi D, Zonari E, Ranghetti A, Berti A, Politi LS, Gentner B, Brown JL, Naldini L, et al: Targeting the ANG2/TIE2 axis inhibits tumor growth and metastasis by impairing angiogenesis and disabling rebounds of proangiogenicmyeloid cells. Cancer Cell 19: 512-526, 2011.

138. Hughes R, Fang HY, Muthana M and Lewis CE: Role of tumour-associated macrophages in the regulation of angiogenesis. Tumour-Associated Macrophages: 17-29, 2011.

139. Giraudo E, Inoue $M$ and Hanahan D: An amino-bisphosphonate targets MMP-9-expressing macrophages and angiogenesis to impair cervical carcinogenesis. J Clin Invest 114: 623-633, 2004.

140. Li ZR, Li YP, Lin ML, Su WR, Zhang WX, Zhang Y, Yao L and Liang D: Activated macrophages induce neovascularizationthrough upregulation of MMP-9 and VEGF in rat corneas. Cornea 31: 1028-1035, 2012.

141. Houghton AM, Grisolano JL, Baumann ML, Kobayashi DK, Hautamaki RD, Nehring LC, Cornelius LA and Shapiro SD: Macrophage elastase (matrix metalloproteinase-12) suppresses growth of lung metastases. Cancer Res 66: 6149-6155, 2006.

142. Guo X, Oshima H, Kitmura T, Taketo MM and Oshima M: Stromal fibroblasts activated by tumor cells promote angiogenesisin mouse gastric cancer. J Biol Chem 283: 19864-19871, 2008.

143. Zhang Y, Tang H, Cai J, Zhang T, Guo J, Feng D and Wang Z: Ovarian cancer-associated fibroblasts contribute to epithelial ovarian carcinoma metastasis by promoting angiogenesis, lymphangiogenesis and tumor cell invasion. Cancer Lett 303: 47-55, 2011.

144. Friedl P and Wolf K: Tumour-cell invasion and migration: Diversityand escape mechanisms. Nat Rev Cancer 3: 362-374, 2003.

145. Steeg PS: Tumor metastasis: Mechanistic insights and clinical challenges. Nat Med 12: 895-904, 2006.

146. Valastyan S and Weinberg RA: Tumor metastasis: Molecular insights and evolving paradigms. Cell 147: 275-292, 2011.

147. Liotta LA, Kleinerman J, Catanzaro P and Rynbrandt D: Degradation of basement membrane by murine tumor cells. J

150. Natl Cancer Inst 58: 1427-1431, 1977.

151. epithelial ovarian carcinoma metastasis by promoting angiogenesis, lymphangiogenesis and tumor cell invasion. Cancer Lett 303: 47-55, 2011.

148. Liotta LA: Tumor invasion and metastases - role of the extracellularmatrix: Rhoads Memorial Award lecture. Cancer Res 46: 1-7, 1986.

149. Fingleton B, Vargo-Gogola T, Crawford HC and Matrisian LM: Matrilysin [MMP-7] expression selects for cells with reduced sensitivity to apoptosis. Neoplasia 3: 459-468, 2001

150. Noë V, Fingleton B, Jacobs K, Crawford HC, Vermeulen S, SteelantW, Bruyneel E, Matrisian LM and Mareel M: Release of an invasionpromoter E-cadherin fragment by matrilysin and stromelysin-1. JCell Sci 114: 111-118, 2001.

151. Sameni M, Dosescu J, Moin K and Sloane BF: Functional imaging of proteolysis: Stromal and inflammatory cells increase tumor proteolysis. Mol Imaging 2: 159-175, 2003.

152. Grimshaw MJ, Hagemann T, Ayhan A, Gillett CE, Binder C andBalkwill FR: A role for endothelin-2 and its receptors in breast tumor cell invasion. Cancer Res 64: 2461-2468, 2004.

153. Sahai E: Mechanisms of cancer cell invasion. Curr Opin Genet Dev15: 87-96, 2005.

154. Gaggioli C, Hooper S, Hidalgo-Carcedo C, Grosse R, Marshall JF, Harrington K and Sahai E: Fibroblast-led collective invasion of carcinoma cells with differing roles for RhoGTPases in leading andfollowing cells. Nat Cell Biol 9: 1392-1400, 2007.

155. Provenzano PP, Eliceiri KW, Campbell JM, Inman DR, White JG and Keely PJ: Collagen reorganization at the tumorstromalinterface facilitates local invasion. BMC Med 4: 38, 2006.

156. Provenzano PP, Inman DR, Eliceiri KW, Trier SM and Keely PJ: Contact guidance mediated three-dimensional cell migrationis regulated by Rho/ROCK-dependent matrix reorganization. Biophys J 95: 5374-5384, 2008.

157. Goetz JG, Minguet S, Navarro-Lérida I, Lazcano JJ, Samaniego R,Calvo E, Tello M, Osteso-Ibáñez T, Pellinen T, Echarri A, et al: Biomechanical remodeling of the microenvironment by stromal caveolin- 1 favors tumor invasion and metastasis. Cell 146: $148-163,2011$

158. Chen J, Yao Y, Gong C, Yu F, Su S, Chen J, Liu B, Deng H, Wang F,Lin L, et al: CCL18 from tumor-associated macrophages promotesbreast cancer metastasis via PITPNM3. Cancer Cell 19: 541-555,2011.

159. Yamaguchi H, Pixley F and Condeelis J: Invadopodia and podosomes in tumor invasion. Eur J Cell Biol 85: 213-218, 2006.

160. Yamaguchi H, Lorenz M, Kempiak S, Sarmiento C, Coniglio S,Symons M, Segall J, Eddy R, Miki H, Takenawa T, et al: Molecular mechanisms of invadopodium formation: The role of the N-WASP-Arp $2 / 3$ complex pathway and cofilin. J Cell Biol 168:441-452, 2005.

161. Buccione R, Orth JD and McNiven MA: Foot and mouth: Podosomes, invadopodia and circular dorsal ruffles. Nat Rev Mol Cell Biol 5: 647-657, 2004.

162. Calle Y, Chou HC, Thrasher AJ and Jones GE: Wiskott-Aldrichsyndrome protein and the cytoskeletal dynamics of dendritic cells.J Pathol 204: 460-469, 2004.

163. Linder S and Aepfelbacher M: Podosomes: Adhesion hot-spots ofinvasive cells. Trends Cell Biol 13: 376-385, 2003.

164. Mizutani K, Miki H, He H, Maruta H and Takenawa T: Essential role of neural Wiskott-Aldrich syndrome protein in podosome formation and degradation of extracellular matrix in src-trans- formed fibroblasts. Cancer Res 62: 669-674, 2002.

165. Moreno-Bueno G, Portillo F and Cano A: Transcriptional regu- lation of cell polarity in EMT and cancer. Oncogene 27: 6958$6969,2008$.

166. Thiery JP: Epithelial-mesenchymal transitions in tumour progression. Nat Rev Cancer 2: 442-454, 2002.

167. Liu R, Li J, Xie K, Zhang T, Lei Y, Chen Y, Zhang L, Huang K, Wang K, Wu H, et al: FGFR4 promotes stroma-induced 
epithelial-to-mesenchymal transition in colorectal cancer. Cancer Res 73: 5926-5935, 2013.

168. Bergers G, Song S, Meyer-Morse N, Bergsland E and Hanahan D:Benefits of targeting both pericytes and endothelial cells in the tumor vasculature with kinase inhibitors. J Clin Invest 111: 1287-1295, 2003.

169. Raza A, Franklin MJ and Dudek AZ: Pericytes and vessel matu-ration during tumor angiogenesis and metastasis. Am J Hematol 85:593-598, 2010.

170. Cooke VG, LeBleu VS, Keskin D, Khan Z, O'Connell JT, Teng Y,Duncan MB, Xie L, Maeda G, Vong S, et al: Pericyte depletionresults in hypoxia-associated epithelial-to-mesenchymal transitionand metastasis mediated by met signaling pathway. Cancer Cell 21:66-81,2012.

171. Cano A, Pérez-Moreno MA, Rodrigo I, Locascio A, Blanco MJ,del Barrio MG, Portillo F and Nieto MA: The transcription factor snail controls epithelial-mesenchymal transitions by repressing E-cadherin expression. Nat Cell Biol 2: 76-83, 2000.Batlle E, Sancho E, Francí C, Domínguez D, Monfar M, Baulida J and García De Herreros A: The transcription factor snail is a repressor of E-cadherin gene expression in epithelial tumour cells. Nat Cell Biol 2: 84-89, 2000.

172. Zhou BP, Deng J, Xia W, Xu J, Li YM, Gunduz M and Hung MC: Dual regulation of Snail by GSK-3beta-mediated phosphorylation in control of epithelial-mesenchymal tran- sition. Nat Cell Biol 6: 931-940, 2004.

173. Wu Y, Deng J, Rychahou PG, Qiu S, Evers BM and Zhou BP: Stabilization of snail by NF-kappaB is required for inflammation-induced cell migration and invasion. Cancer Cell 15: 416-428, 2009.

174. Quigley JP and Armstrong PB: Tumor cell intravasation alu-cidated: The chick embryo opens the window. Cell 94:281$284,1998$.

175. Wyckoff JB, Jones JG, Condeelis JS and Segall JE: A critical step in metastasis: In vivo analysis of intravasation at the primary tumor. Cancer Res 60: 2504-2511, 2000.

176. Wolf MJ, Hoos A, Bauer J, Boettcher S, Knust M, Weber A, Simonavicius N, Schneider C, Lang M, Stürzl M, et al: Endothelial CCR2 signaling induced by colon carcinoma cells enables extravasation via the JAK2-Stat5 and p38MAPK pathway. Cancer Cell 22: 91-105, 2012.

177. Gay LJ and Felding-Habermann B: Contribution of platelets to tumour metastasis. Nat Rev Cancer 11: 123-134, 2011.

178. Nagrath S, Sequist LV, Maheswaran S, Bell DW, Irimia D, Ulkus L, Smith MR, Kwak EL, Digumarthy S, Muzikansky A, et al: Isolation of rare circulating tumour cells in cancer patients by microchip technology. Nature 450: 1235-1239, 2007.

179. Huang YY, Hoshino K, Chen P, Wu CH, Lane N, Huebschman M, Liu H, Sokolov K, Uhr JW, Frenkel EP, et al: Immunomagnetic nanoscreening of circulating tumor cells with a motion controlled microfluidic system. Biomed Microdevices 15: 673-681, 2013.

180. Cai H and Peng F: 2-NBDG fluorescence imaging of hyper- metabolic circulating tumor cells in mouse xenograft model of breast cancer. J Fluoresc 23: 213-220, 2013.

181. Nieswandt B, Hafner M, Echtenacher B and Männel DN: Lysis of tumor cells by natural killer cells in mice is impeded by platelets. Cancer Res 59: 1295-1300, 1999.

182. Mbeunkui $\mathrm{F}$ and Johann DJ Jr: Cancer and the tumor micro- environment: A review of an essential relationship. Cancer Chemother Pharmacol 63: 571-582, 2009.

183. Gupta GP, Nguyen DX, Chiang AC, Bos PD, Kim JY, Nadal C, Gomis RR, Manova-Todorova K and Massagué J: Mediators of vascular remodelling co-opted for sequential steps in lung metastasis. Nature 446: 765-770, 2007.

184. Psaila B, Kaplan RN, Port ER and Lyden D: Priming the 'soil' for breast cancer metastasis: The pre-metastatic niche. Breast Dis 26: 65-74, 2006-2007.

185. Psaila B and Lyden D: The metastatic niche: Adapting theforeign soil. Nat Rev Cancer 9: 285-293, 2009.

186. Hiratsuka S, Watanabe A, Aburatani H and Maru Y: Tumour- mediated upregulation of chemoattractants and recruitment of myeloid cells predetermines lung metastasis. Nat Cell Biol 8: 1369-1375, 2006.

187. Rafii S and Lyden D: S100 chemokines mediate bookmarking of premetastatic niches. Nat Cell Biol 8: 1321-1323, 2006.

188. Hiratsuka S, Watanabe A, Sakurai Y, Akashi-Takamura S, Ishibashi S, Miyake K, Shibuya M, Akira S, Aburatani H and Maru Y: The S100A8-serum amyloid A3-TLR4 paracrine cascade establishes a pre-metastatic phase. Nat Cell Biol 10: 1349-1355, 2008.

189. Kaplan RN, Riba RD, Zacharoulis S, Bramley AH, Vincent L, Costa C, MacDonald DD, Jin DK, Shido K, Kerns SA, et al: VEGFR1-positive haematopoietic bone marrow progenitors initiate the pre-metastatic niche. Nature 438: 820-827, 2005.

190. Nakasone ES, Askautrud HA, Kees T, Park JH, Plaks V, Ewald AJ, Fein M, Rasch MG, Tan YX, Qiu J, et al: Imaging tumor-stroma interactions during chemotherapy reveals contributions of the microenvironment to resistance. CancerCell 21: 488-503, 2012.

191. Roodhart JM, Daenen LG, Stigter EC, Prins HJ, GerritsJ, Houthuijzen JM, Gerritsen MG, Schipper HS, 10

192. Backer MJ, van Amersfoort M, et al:

193. Mesenchymal stem cells induce resistance to chemotherapy through the release of platinum-induced fatty acids. Cancer Cell 20: 370-383, 2011.

Joosse SA and

197 Pantel K: Tumor-educated platelets as liquid biopsy in cancer patients. Cancer Cell 28: 552-554, 2015.

194. Wong HK, Fatimy RE, Onodera C, Wei Z, Yi M, Mohan A, Gowrisankaran S, Karmali P, Marcusson E, Wakimoto H, et al: The Cancer Genome Atlas Analysis predicts microRNA for targeting cancer growth and vascularization in glioblastoma. Mol Ther 23: 1234-1247, 2015.

195. Resnick MJ, Lopatin M, Shore ND, Lam PN, Helfand B, Abramson RD, Crager M, Bonham M, Tezcan H, ClarkLangone KM, et al: Analysis of tumor DNA in urine as a highly sensitive liquid biopsy for patients with non-muscle invasive bladder cancer (NMIBC). Clin Cancer Res 22: 14, 2016.

196. Mishra RK, Wei C, Hresko RC, Bajpai R, Heitmeier M, Matulis SM, Nooka AK, Rosen ST, Hruz PW, Schiltz GE,et al: In silico modeling-based identification of glucose trans- porter 4 (GLUT4)-selective inhibitors for cancer therapy. $\mathrm{J}$ BiolChem 290: 14441-14453, 2015.

197. Tuxhorn JA, McAlhany SJ, Yang F, Dang TD and Rowley DR: Inhibition of transforming growth factor-beta activity decreases angiogenesis in a human prostate cancer-reactive stroma xenograft model. Cancer Res 62: 6021-6025, 2002. 
198. Carmeliet P: Angiogenesis in health and disease. Nat Med 9: 653-660, 2003.

199. Joyce JA, Freeman C, Meyer-Morse N, Parish CR and Hanahan D: A functional heparan sulfate mimetic implicates both heparanase and heparan sulfate in tumor angiogenesis and invasion in a mouse model of multistage cancer. Oncogene 24: 4037-4051, 2005.

200. Hamano Y, Zeisberg M, Sugimoto H, Lively JC, Maeshima Y, Yang C, Hynes RO, Werb Z, Sudhakar A and Kalluri R: Physiological levels of tumstatin, a fragment of collagen IV alpha3chain, are generated by MMP-9 proteolysis and suppress angio-genesis via alphaV beta3 integrin. Cancer Cell 3: 589-601, 2003.

201. Rudland PS, Platt-Higgins A, El-Tanani M, De Silva Rudland S, Barraclough R, Winstanley JH, Howitt R and West CR: Prognosticsignificance of the metastasis-associated protein osteopontin in human breast cancer. Cancer Res 62: 3417-3427, 2002.

202. El-Tanani MK, Campbell FC, Kurisetty V, Jin D, McCann M and Rudland PS: The regulation and role of osteopontin in malignant transformation and cancer. Cytokine Growth Factor Rev 17: 463-474, 2006.

203. Tuck AB and Chambers AF: The role of osteopontin in breast cancer: Clinical and experimental studies. J Mammary Gland Biol Neoplasia 6: 419-429, 2001

204. Weber GF: The metastasis gene osteopontin: A candidate targetfor cancer therapy. Biochim Biophys Acta 1552: 61-85, 2001.

205. Matarrese P, Fusco O, Tinari N, Natoli C, Liu FT, Semeraro ML, Malorni W and Iacobelli S: Galectin-3 overexpression protects from apoptosis by improving cell adhesion properties. Int J Cancer 85: 545-554, 2000.

206. Inohara H, Honjo Y, Yoshii T, Akahani S, Yoshida J, Hattori K,Okamoto S, Sawada T, Raz A and Kubo T: Expression of galectin-3 in fine-needle aspirates as a diagnostic marker differ- entiating benign from malignant thyroid neoplasms. Cancer 85: 2475-2484, 1999.

207. Pinedo HM, Verheul HM, D'Amato RJ and Folkman J: Involvement of platelets in tumour angiogenesis? Lancet 352 : 1775-1777, 1998.

208. Pai R, Soreghan B, Szabo IL, Pavelka M, Baatar D and Tarnawski AS: Prostaglandin E2 transactivates EGF receptor:A novel mechanism for promoting colon cancer growth and gastrointestinal hypertrophy. Nat Med 8: 289-293, 2002.

209. Ikushima H and Miyazono K: TGFbeta signalling: A complex web in cancer progression. Nat Rev Cancer 10: 415-424, 2010.

210. Sierko E and Wojtukiewicz MZ: Platelets and angiogenesis in malignancy. Semin Thromb Hemost 30: 95-108, 2004.

211. Medina VA and Rivera ES: Histamine receptors and cancer pharmacology. Br J Pharmacol 161: 755-767, 2010.

212. Moghaddam A, Zhang HT, Fan TP, Hu DE, Lees VC, Turley H,Fox SB, Gatter KC, Harris AL and Bicknell R: Thymidine phos-phorylase is angiogenic and promotes tumor growth. Proc Natl Acad Sci USA 92: 998-1002, 1995.

213. Bronckaers A, Gago F, Balzarini J and Liekens S: The dual role of thymidine phosphorylase in cancer development and chemo- therapy. Med Res Rev 29: 903-953, 2009.

214. Geiger TR and Peeper DS: Critical role for TrkB kinase function in anoikis suppression, tumorigenesis, and metastasis. Cancer Res 67: 6221-6229, 2007.

215. Kim YJ, Borsig L, Varki NM and Varki A: P-selectin deficiencyattenuates tumor growth and metastasis. Proc Natl Acad Sci USA 95: 9325-9330, 1998.David M, Wannecq E, Descotes F, Jansen S, Deux B, Ribeiro J, Serre CM, Grès S, Bendriss-Vermare N, Bollen M, et al: Cancercell expression of autotaxin controls bone metastasis formation in mouse through lysophosphatidic acid-dependent activation of osteoclasts. PLoS One 5: e9741, 2010.

216. Visentin B, Vekich JA, Sibbald BJ, Cavalli AL, Moreno KM, Matteo RG, Garland WA, Lu Y, Yu S, Hall HS, et al: Validation of an anti-sphingosine-1-phosphate antibody as a potential therapeutic in reducing growth, invasion, and angiogenesis in multiple tumor lineages. Cancer Cell 9: 225-238, 2006.

217. Ruf W and Mueller BM: Thrombin generation and the patho- genesis of cancer. Semin Thromb Hemost 32 (Suppl 1): 6168, 2006.

218. Bajou K, Noël A, Gerard RD, Masson V, Brunner N, Holst-Hansen C, Skobe M, Fusenig NE, Carmeliet P, Collen D, et al: Absence of host plasminogen activator inhibitor 1 preventscancer invasion and vascularization. Nat Med 4: 923-928, 1998.

219. Falcón BL, Hashizume H, Koumoutsakos P, Chou J, Bready JV,Coxon A, Oliner JD and McDonald DM: Contrasting actions of selective inhibitors of angiopoietin-1 and angiopoietin-2 on the normalization of tumor blood vessels. Am J Pathol 175: 2159-2170, 2009.

220. Payne AS and Cornelius LA: The role of chemokines in melanoma tumor growth and metastasis. J Invest Dermatol 118: 915-922, 2002.

221. Wu Y, Li YY, Matsushima K, Baba T and Mukaida N: CCL3-CCR5 axis regulates intratumoral accumulation of leukocytes and fibroblasts and promotes angiogenesis in murine lung metastasis process. J Immunol 181: 6384-6393, 2008.

222. Läubli H, Spanaus KS and Borsig L: Selectin-mediated activation of endothelial cells induces expression of CCL5 and promotes metastasis through recruitment of monocytes. Blood 114: 4583-4591, 2009.

223. Yi F, Jaffe R and Prochownik EV: The CCL6 chemokine is differentially regulated by c-Myc and L-Myc, and promotes tumorigenesis and metastasis. Cancer Res 63: 2923-2932, 2003.

224. Keeley EC, Mehrad B and Strieter RM: CXC chemokines in cancer angiogenesis and metastases. Adv Cancer Res 106: 91-111, 2010.

225. Nakamura ES, Koizumi K, Kobayashi M, Saitoh Y, Arita Y, Nakayama T, Sakurai H, Yoshie O and Saiki I: RANKLinducedCCL22/macrophage-derived chemokine produced from osteo- clasts potentially promotes the bone metastasis of lung cancer expressing its receptor CCR4. Clin Exp Metastasis 23: 9-18, 2006.

226. Romagnani P, Lasagni L, Annunziato F, Serio M and Romagnani S: CXC chemokines: The regulatory link between inflammation and angiogenesis. Trends Immunol 25: 201-209, 2004.

227. Strieter RM, Burdick MD, Gomperts BN, Belperio JA and Keane MP: CXC chemokines in angiogenesis. Cytokine GrowthFactor Rev 16: 593-609, 2005.

228. Feliciano P: CXCL1 and CXCL2 link metastasis and chemore- sistance. Nat Genet 44: 840, 2012.

229. Keane MP, Belperio JA, Xue YY, Burdick MD and Strieter RM: Depletion of CXCR2 inhibits tumor growth and 
angiogenesisin a murine model of lung cancer. J Immunol 172: 2853-2860, 2004.

230. White ES, Flaherty KR, Carskadon S, Brant A, Iannettoni MD, Yee J, Orringer MB and Arenberg DA: Macrophage migration inhibitory factor and CXC chemokine expression in non-small cell lung cancer: Role in angiogenesis and prognosis. Clin Cancer Res 9: 853-860, 2003.

231. Strieter RM, Burdick MD, Mestas J, Gomperts B, Keane MP and Belperio JA: Cancer CXC chemokine networks and tumourangiogenesis. Eur J Cancer 42: 768-778, 2006.

232. Miyazaki H, Patel V, Wang H, Edmunds RK, Gutkind JS and Yeudall WA: Down-regulation of CXCL5 inhibits squamous carcinogenesis. Cancer Res 66: 4279-4284, 2006.

233. Gijsbers K, Gouwy M, Struyf S, Wuyts A, Proost P, Opdenakker G, Penninckx F, Ectors N, Geboes K and Van Damme J: GCP-2/CXCL6 synergizes with other endo-thelial cell-derived chemokines in neutrophil mobilization and is associated with angiogenesis in gastrointestinal tumors. Exp Cell Res 303: 331-342, 2005.

234. Verbeke H, Struyf S, Berghmans N, Van Coillie E, Opdenakker G, Uyttenhove C, Van Snick J and Van Damme J: Isotypic neutralizing antibodies against mouse GCP-2/CXCL6 inhibit melanoma growth and metastasis. Cancer Lett 302: 54-62, 2011.

235. Tang Z, Yu M, Miller F, Berk RS, Tromp G and Kosir MA: Increased invasion through basement membrane by CXCL7-transfected breast cells. Am J Surg 196: 690-696, 2008.

236. Bachelder RE, Wendt MA and Mercurio AM: Vascular endo- thelial growth factor promotes breast carcinoma invasion in an autocrine manner by regulating the chemokine receptor CXCR4.Cancer Res 62: 7203-7206, 2002.

237. Belperio JA, Phillips RJ, Burdick MD, Lutz M, Keane M and Strieter R: The SDF-1/CXCL 12/CXCR4 biological axis in non-small cell lung cancer metastases. Chest 125 (Suppl 5): 156S, 2004.

238. Pan J, Mestas J, Burdick MD, Phillips RJ, Thomas GV, Reckamp K, Belperio JA and Strieter RM: Stromal derived factor-1 (SDF-1/CXCL12) and CXCR4 in renal cell carcinoma metastasis. Mol Cancer 5: 56, 2006. 